\title{
Postural counseling represents a novel option in pain management of fibromyalgia patients [Erratum]
}

Galvani C, Caramaschi P, Mura P, et al. J Pain Res. 2019;12: $327-337$

On page 336, the wrong author name was given in part of the author contributions section. The correct details follow.

\section{Author contributions}

P Caramaschi, D Biasi and A Carletto were the rheumatologists in charge of FM patients, and they collected and analyzed the patients' data and wrote the paper. C Galvani and G Ongaro were the counselor physiotherapists involved in FM treatment, collected illness narratives, analyzed the data and wrote the paper. L De Franceschi, P Mura, M Evangelista, A Paladini and $G$ Finco analyzed the data and wrote the paper. A Ciannameo, A Pari, and E Arnaudo carried out the interviews, analyzed the data and wrote the paper. A Piroli and G Varrassi wrote and reviewed the paper and A Piroli also approved the text. All authors contributed toward data analysis, drafting and critically revising the paper, gave final approval of the version to be published, and agree to be accountable for all aspects of the work.
Journal of Pain Research

\section{Publish your work in this journal}

The Journal of Pain Research is an international, peer reviewed, open access, online journal that welcomes laboratory and clinical findings in the fields of pain research and the prevention and management of pain. Original research, reviews, symposium reports, hypothesis formation and commentaries are all considered for publication.

\section{Dovepress}

The manuscript management system is completely online and includes a very quick and fair peer-review system, which is all easy to use. Visit http://www.dovepress.com/testimonials.php to read real quotes from published authors. 